\title{
PHYSICOCHEMICAL CHARACTERISTICS OF WHEAT TREATED WITH DIATOMACEOUS EARTH AND CONVENTIONALLY STORED
}

\author{
Características físico-químicas de trigo tratado com terra de \\ diatomácea e armazenado em sistema convencional
}

\author{
Janete Deliberali Freo' ${ }^{1}$ Lidiane Borges Dias de Moraes $^{2}$, Gabriela Soster Santetti ${ }^{3}$, \\ Taís Luana Gottmannshausen ${ }^{3}$, Moacir Cardoso Elias ${ }^{1}$, Luiz Carlos Gutkoski ${ }^{4}$
}

\begin{abstract}
Studies show the efficacy of the use of diatomaceous earth for insect control, however, lack studies on the effects of physical and chemical properties of wheat flour added diatomaceous earth. The aim of this study was to assess the physicochemical characteristics of wheat grains treated with increasingly higher dosages of diatomaceous earth and conventionally stored for a 180 -day period. Samples containing $10 \mathrm{~kg}$ of wheat grains were treated with $0.0,2.0$ and $4.0 \mathrm{~g} \mathrm{~kg}^{-1}$ of diatomaceous earth and then conventionally stored. Analyses of grain hectoliter mass and ash content, as well as flour gluten content, flour color, alveography and farinography were performed at 0,60,120 and 180 days of storage. The experiment was carried out in a totally randomized design. The grain ash content and intensity of color component $\mathrm{L}^{*}$ of wheat flour increase proportionally to the application of increasing doses of diatomaceous earth and longer storage periods. The grain hectoliter mass and values of $+b^{*}$ chromaticity coordinate, wet gluten content and gluten content in wheat flour diminish with the application of increasing doses of diatomaceous earth and longer storage periods. The gluten strength and dough stability of flour obtained from wheat grains without addition of diatomaceous earth increase with the storage period; this behavior was not observed in treatments with the application of 2.0 and $4.0 \mathrm{~g} \mathrm{~kg}^{-1}$ diatomaceous earth. The application of increasing doses of diatomaceous earth changes the physical and chemical characteristics of wheat grains stored, with consequent reduction of the flour technological quality.
\end{abstract}

Index terms: Triticum aestivum, storage, industrial quality, alveography, gluten.

\begin{abstract}
RESUMO
Pesquisas evidenciam a eficácia do o uso de terra de diatomáceas no controle de insetos, entretanto, faltam estudos sobre os efeitos das propriedades físicas e químicas de farinha de trigo adicionadas de terra de diatomácea. Neste trabalho, foram avaliadas as características físicas e químicas de grãos de trigo, tratados com doses crescentes de terra de diatomácea e armazenados no sistema convencional, pelo período de 180 dias. As amostras foram tratadas com terra de diatomácea nas doses de zero, 2,0 e 4,0 g kg-1 e armazenadas no sistema convencional. Nos períodos zero, 60, 120 e 180 dias de armazenamento, foram realizadas as análises de massa de hectolitro e cinzas de grãos de trigo; teor de glúten, cor, alveografia e farinografia da farinha de trigo. O experimento foi conduzido em delineamento inteiramente casualizado. O teor de cinzas do grão e a intensidade de cor do componente L* aumentam proporcionalmente com a aplicação de doses crescentes de terra de diatomácea e períodos de armazenamento. A massa de hectolitro e os valores da coordenada de cromaticidade $+b^{*}$, teor de glúten úmido e índice de glúten da farinha, diminuem com doses crescentes de terra de diatomácea e períodos de armazenamento. A força de glúten e estabilidade da massa da farinha de trigo sem adição de terra de diatomácea aumentaram com o período de armazenamento. A aplicação de doses crescentes de terra de diatomácea altera as características físicas e químicas dos grãos de trigo armazenados com consequente redução da qualidade tecnológica da farinha de trigo.
\end{abstract}

Termos para indexação: Triticum aestivum, armazenamento, qualidade industrial, alveografia, glúten.

\section{INTRODUCTION}

Diatomaceous earth, usually called inert powder, is an amorphous sediment originated from carapaces of unicellular vegetable organisms, such as microscopic aquatic algae, found in marine and lacustrine environments. Due to its siliceous nature, frustules develop on the geological layers of the Earth crust. Diatomaceous earth is a light material with low apparent specific mass, whose color ranges from white to dark gray. This material is mainly composed of $80-93 \%$ silicon oxide, clay minerals, organic material, hydroxides, quartzitic sand, and calcium and magnesium carbonates (Korunic; Cenkowski; Fields, 1998; Vardeman et al., 2007).

Diatomaceous earth is extracted from fossilized deposits, then dried, triturated and ground into a fine

\footnotetext{
${ }^{1}$ Universidade Federal de Pelotas/UFPEL - Faculdade de Agronomia Eliseu Maciel - Pelotas - RS - Brasil

${ }^{2}$ Instituto Federal do Rio Grande do Sul/IFRS - Campus Sertão - RS - Brasil

${ }^{3}$ Universidade de Passo Fundo/UPF - Engenharia de Alimentos - Passo Fundo - RS - Brasil

${ }^{4}$ Universidade de Passo Fundo/UPF - Faculdade de Agronomia - Campus Universitário - 99001-970 - Passo Fundo - RS - Brasil - gutkoski@upf.br Received in may 27, 2014 and approved in september 1, 2014
}

Ciênc. Agrotec., Lavras, v.38, n.6, p.546-553, nov./dez., 2014 
powder for commercial use. It is a non-toxic product used to control pests in stored grains and does not cause resistance in insects (Lorini et al., 2003; Atui et al., 2003). It acts by means of dehydration or desiccation, as powder particles adhere to the insects' bodies and remove lipids from the cuticle, thus causing abrasion in the tegument and excessive water loss (Vardeman et al., 2007).

The application of diatomaceous earth to grains has caused some problems, such as changes in physical and mechanical properties, reducing both flowability and density, with visible presence of residuals. Additional problems caused by treated wheat grains are the effect of abrasion on the equipments and the longer time taken by the milling process (Lorini, 2002). The quality of cereal grains and flours is determined by a range of characteristics that have different meanings, depending on either the purpose of use or the type of product (Abid; Hussain, 2009). The flour rheological evaluation is fundamental to the bread-making industry, as it helps predict the characteristics of dough processing and the quality of end products. It includes a set of analyses in which the bread-making test must be necessarily included (Gutkoski; Jacobsen Neto, 2002).

Although there are studies evidencing the effectiveness of using diatomaceous earth for insect control (Lorini et al., 2003), studies of the effects of this powder on the physical and chemical properties of wheat flour are still insufficient, and there is a need for further scientific investigation. The aim of this study was to assess the physical and chemical characteristics of wheat grains treated with increasing dosages of diatomaceous earth and conventionally stored for a 180 days.

\section{MATERIAL AND METHODS}

The experiment was carried out in the Laboratory of Cereals of the Food Research Center (CEPA), University of Passo Fundo, in Rio Grande do Sul, and in the Laboratory of Grain Post-Harvest, Industrialization and Quality, of the School of Agronomy Eliseu Maciel, at the Federal University of Pelotas, in Rio Grande do Sul.

Wheat (Triticum aestivum L.) used was Abalone cultivar (2008/2009 harvest), wich is classified as bread wheat ( $\mathrm{W}=255)$, presents hard red grain and grain weight averaged $31.1 \mathrm{~g}$, produced at Sementes e Cabanha Butiá, in the city of Coxilha, RS, situated at latitude $28^{\circ} 05^{\prime} 12,3^{\prime \prime}$ and longitude $52^{\circ} 23^{\prime} 23^{\prime \prime}$. The soil in the experimental area, $0-0.15 \mathrm{~m}$ deep, classified as typical dystrophic red latosoil (Santos et al., 2006), presented the following chemical properties before the experiment: $\mathrm{pH}$ (water) $=5.5$; O.M. $=4.0 \mathrm{~g} \mathrm{~kg}^{-1} ; \mathrm{Al}^{3+}=0.2$ cmolc. $\mathrm{L} ; \mathrm{Ca}^{2+}=4.8$ cmolc.L; $\mathrm{Mg}^{2+}$
$=2.6 \mathrm{cmolc} . \mathrm{L} ; \mathrm{P}=52.0 \mathrm{mg} . \mathrm{L} ; \mathrm{K}=323 \mathrm{mg} . \mathrm{L}$ and $\mathrm{S}=10.0$ mg.L, which were determined using the methods described by Tedesco, Volkweiss and Bohen (1985).

Grains were harvested with the use of a selfpropelled harvester. Later, pre-cleaning was performed in air-screen machine and sieves; grains were dried in stationary dryer until humidity reached $13 \%$. Diatomaceous earth used was KeepDry ${ }^{\circledR}$, Brazil, with approximately 93\% amorphous silica dioxide $\left(\mathrm{SiO}_{2}\right)$, mean particle size of $15 \mu \mathrm{m}$, and apparent density of $200 \mathrm{~g} . \mathrm{L}^{-1}$, light colored, insoluble in water and aspect of dry powder.

The experiment was carried out in a completely randomized design, with a $3 \times 4$ factorial distribution (dosages of diatomaceous earth $\mathrm{x}$ storage periods), totalizing 12 managements, with three repetitions for each management. Samples containing $10 \mathrm{~kg}$ of wheat grains were treated with $0.0,2.0$ and $4.0 \mathrm{~g} \mathrm{~kg}^{-1}$ of diatomaceous earth (DE). The samples were homogenized in a Hypo, HB 25 planetary mixer (Brazil), packed in cotton bags and stored at $22{ }^{\circ} \mathrm{C}$ and $70 \pm 5 \%$ of relative humidity. The concentrations of diatomaceous earth were defined based on indications of research (Lorini, 2012), being employed the control treatment and two treatments with the product, the recommended dose and the other with a double dose. Analyses of grain hectoliter mass (HM) and ash content, as well as flour gluten content, color, alveography and farinography were performed at $0,60,120$ and 180 days of storage. Wheat was milled in a pilot mill (Chopin CD1, France), according to AACC (2000) method 26-10.

The hectoliter mass was determined according to the Rules for Seed Analysis (Brasil, 2009), using a Dalle Molle balance, and the results were expressed in $\mathrm{kg} \mathrm{hL}^{-1}$.

Ash content was determined according to AACC (2000) method 08-01. The analyses were performed in duplicate, and the results were given in percentage, on a dry basis.

Gluten content was determined using a Gluten Perten Instruments apparatus (model 2200, Sweden) according to AACC (2000) method 38-12, with a 10gram sample, corrected for $14 \%$ of humidity, with two repetitions, to obtain the wet gluten content and the gluten index.

The color of wheat flour samples was determined in a spectrophotometer HunterLab ${ }^{\circledR}$ (ColorQuest II Sphere, England), with sphere geometric optical sensor, following AACC (2000) method 14-22 in triplicate. The values obtained are expressed in $\mathrm{L}^{*}$ (lightness) and $+\mathrm{b}^{*}$ chromaticity coordinate (yellow).

The wheat flour viscoelastic characteristics were determined using a Chopin alveograph (model NG, 
France) according to AACC method 54-30, by weighing $250 \mathrm{~g}$ of flour and $129.4 \mathrm{~mL}$ of water, corrected on a basis of $14 \%$ of moisture. The parameters obtained from the alveogram were tenacity $(\mathrm{P})$, which measures the maximum overpressure on dough expansion $(\mathrm{mm})$; extensibility (L), which measures the curve length ( $\mathrm{mm}$ ); and deformation energy (W), which corresponds to the mechanical work required to expand a bubble until its rupture, expressed in $10^{-4} \mathrm{~J}$.

The characteristics of the wheat flour blend were determined using a Max Egger promylograph (model $\mathrm{T} 6$, Austria) for $100 \mathrm{~g}$ of wheat flour. The analysis was performed according to AACC (2000) method 54-21. The parameters assessed were water absorption, which indicates the flour quality through the gluten intumescence capacity; development time, which corresponds to the period from the first water addition to the maximum consistency point (peak); and stability, which is defined as the time difference between the point at which the top of the curve intercepts the mean line and the curve point that leaves the line.

The results were subject to variance analysis (ANOVA); in the significant models, the means were compared using the Tukey test at 5\%, and regression analysis was performed among the response variables. Data processing and statistical analysis were conducted using the statistical software Sisvar ${ }^{\circledR}$ Version 5.3, Build 75 (Ferreira, 2010). The analyses and graphs of regression equations were performed with the use of Origin 5.0 program.

\section{RESULTS AND DISCUSSION}

The mean squares of variance analysis for storage time and dosages of diatomaceous earth were significant $(\mathrm{p} \leq 0.05)$ in the determinations of hectoliter mass, ashes, color $\mathrm{L}^{*}$ components (lightness) and $+b^{*}$ (yellow), wet gluten and gluten index. The time $\mathrm{x}$ dosage interaction was significant for the determination of hectoliter mass, ashes, color $\mathrm{L}^{*}$ components (lightness), $+\mathrm{b}^{*}$ (yellow) and wet gluten. The coefficients of variation for the determinations showed values of reduced magnitude. This ensures adequate control of the experimental techniques to conduct the experiment, and reliability of the results obtained from this study (Table 1).

The statistical analysis showed a significant difference $(p<0.05)$ for ash content in all the managements studied (Figure 1a). The regression equations were significant; quadratic terms were used for adjustment, with coefficients of determination ranging from 0.96 to 0.98 . With regard to storage time, there were increased ash contents in all the managements; higher values were found for flour samples of wheat treated with 2.0 and $4.0 \mathrm{~g} \mathrm{~kg}^{-1}$ of diatomaceous earth. Such increase is related both to the dosage of diatomaceous earth applied to wheat grains containing approximately $93 \%$ amorphous silicon dioxide and to the degradation of the organic fraction during the storage period. According to Bhattacharya and Raha (2002), such degradation is caused by the metabolic activities of grains and microorganisms, which consume organic material, producing carbonic gas, water, heat and other products, thus changing the wheat grain ash content. Hence, the ash content proportionally reaches higher values, as the organic matter is consumed. Korunic et al. (1996) did not find higher ash content in wheat grains treated with diatomaceous earth; however, when they added diatomaceous earth directly to the flour, the ash content increased.

Table 1 - Variance analysis for the determinations of hectoliter mass (HM) and ashes in grains, and intensity of color components $\mathrm{L}^{*}$ (lightness), $+\mathrm{b}^{*}$ (yellow), wet gluten (WG) and gluten index (GI) in flour from wheat treated with diatomaceous earth and stored for 180 days.

\begin{tabular}{|c|c|c|c|c|c|c|c|}
\hline Source of variation & DL & HM & Ashes & $\mathrm{L}^{*}$ & $+b^{*}$ & WG & GI \\
\hline & \multicolumn{7}{|c|}{ 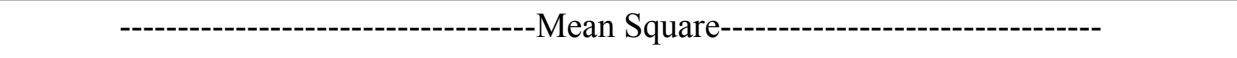 } \\
\hline Time (days) & 3 & $4.05^{*}$ & $1.62 *$ & $0.016^{*}$ & $2.32 *$ & $59.21 *$ & $16.56^{*}$ \\
\hline Dose $(g)$ & 2 & $150.22 *$ & $6.43^{*}$ & $0.139 *$ & $9.36^{*}$ & $12.30^{*}$ & $2.63 *$ \\
\hline Time $\mathrm{x}$ earth & 6 & $0.32 *$ & $0.019^{*}$ & $0.001 *$ & $0.09 *$ & $7.18^{*}$ & $0.58^{\mathrm{ns}}$ \\
\hline Total & & 35 & 35 & 35 & 35 & 35 & 35 \\
\hline CV $(\%)$ & & 0.26 & 0.41 & 0.66 & 0.06 & 0.85 & 0.66 \\
\hline
\end{tabular}

$\mathrm{DL}$ - Degrees of liberty; CV - Coefficient of variation (\%); * - Significant at $5 \%$ probability ( $\leq \leq 0.05)$; ns - non-significant at $5 \%$ of probability $(\mathrm{p}>0.05)$. 
The HM values showed significant differences $(p<0.05)$ in relation to both the storage period and the different dosages of diatomaceous earth applied to the grains (Figure 1b). The regression equations were significant, and the quadratic terms were used for adjustment, with coefficients of determination above 0.80 . With the storage period, HM values diminished proportionally in all managements. Such results are in accordance with Fleurat-Lessard (2002) who reported that, with a longer storage time, there is HM reduction due to the consumption of grain organic components. $\mathrm{HM}$ values reflect the total quantitative losses resulting from the processes of grain deterioration due to their intrinsic metabolism and the activity of microbes and associated pests.

With regard to the effect of different dosages of diatomaceous earth on HM, the lowest values were observed in managements DE2 and DE4 (Figure 1b). This reduction, compared to DE0, is likely to be related to the decreased flowability and density of grains treated with diatomaceous earth. Similar results were reported by Korunic, Cenkowski and Fields (1998). Considering the HM result, which is one of the criteria for wheat classification in Brazil, according to IN nr. 7, from August $15^{\text {th }}, 2001$, grains resulting from treatments DE2 and DE4 did not reach the minimum values to be classified as Type 1 .

Over the storage time, the wheat flour became lighter, showing a significant increase in the intensity of the color L* component (lightness), in which the

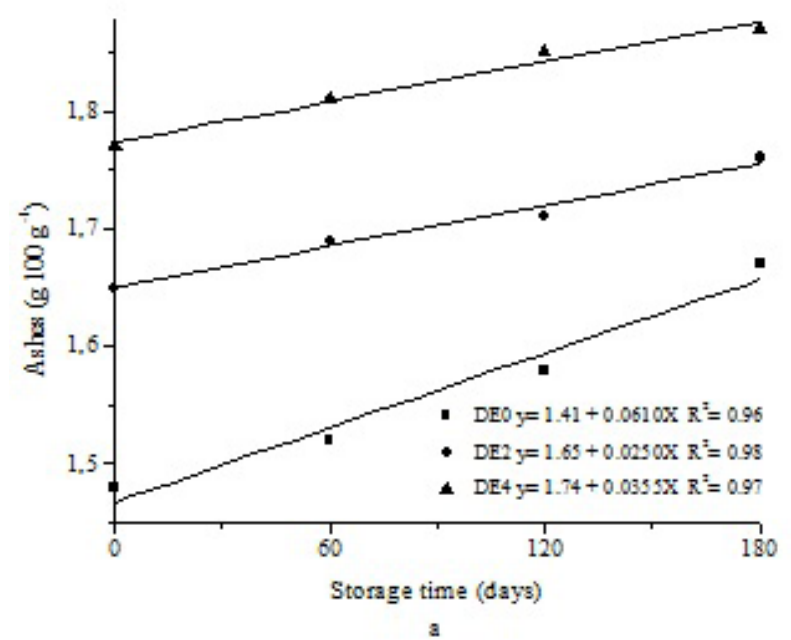

regression equations DE0, DE2 and DE4 showed coefficient of determination between 0.89 and 0.97 (Figure 2a). The intensity of the color $\mathrm{L}^{*}$ component (lightness) of wheat flour DE0 was higher than the other treatments during the whole storage period. On the other hand, in treatments DE2 and DE4, this component was affected by the residuals of diatomaceous earth present in the flour, thus reducing the lightness measures.

Along the storage time, $+b^{*}$ chromaticity coordinate (yellow) diminished, and this was significant in all the regression models studied, with coefficients of determination ranging from 0.95 to 0.99 (Figure $2 b$ ). Such alteration was probably due to the natural process of maturation of wheat grains. The lowest values of $+b *$ chromaticity coordinate were found in the treatments that contained higher dosages of diatomaceous earth.

With storage time, there was an increase in values of $\mathrm{L}^{*}$ and reduction of $+\mathrm{b}^{*}$, but such color alterations were significantly higher in treatments DE2 and DE4. The inclination of the straight lines determined by the regression equations along the storage period was similar for color components $\mathrm{L}^{*}$ and $+\mathrm{b}^{*}$ in different doses of diatomaceous earth. According to Peterson et al. (2001), Gutkoski et al. (2008) and Ortolan et al. (2010), such alterations are related to the content of bran or extraneous material remaining in the flour as well as to the amount of pigments, which undergo oxidation during the storage period.

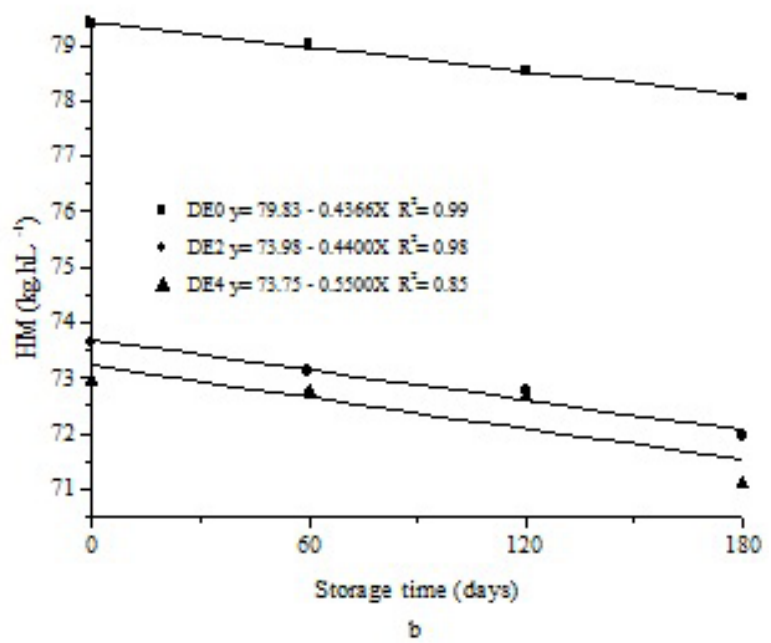

Figure 1 - Ashes content $\left(\mathrm{g} \mathrm{100^{-1 }}\right)(\mathrm{a})$ and hectoliter mass $\left(\mathrm{kg} \mathrm{hL}^{-1}\right)(\mathrm{b})$ in wheat grains treated with diatomaceous earth and stored for 180 days. 
The adjustments obtained from the regression analysis showed decreased wet gluten content in all managements along the storage period (Figure 3a). Treatment DE0 presented higher content of wet gluten in comparison to the others, with a decrease of $6.06 \%$. The lower contents of wet gluten was verified on DE2 treatment (reduction of 7.39\%) followed by DE4 (down $8.46 \%$ ) and may be related to the effect provoked by the residuals of diatomaceous earth in the flour, which altered the dielectric constant, or ionic force, of the aqueous solution, leading to protein precipitation forming of gluten. In the study of different times of harvest, drying and storage in grain wheat quality of common and durum also was observed reducing the content of wet gluten with storage time (Carneiro et al. 2005).

Concerning gluten index, the regression equations were significant, and quadratic terms were used for adjustment, with coefficients of determination ranging from 0.70 to 0.96 (Figure $3 \mathrm{~b}$ ). Over the storage time, the gluten index decreased in all the managements studied, and lower values were found for
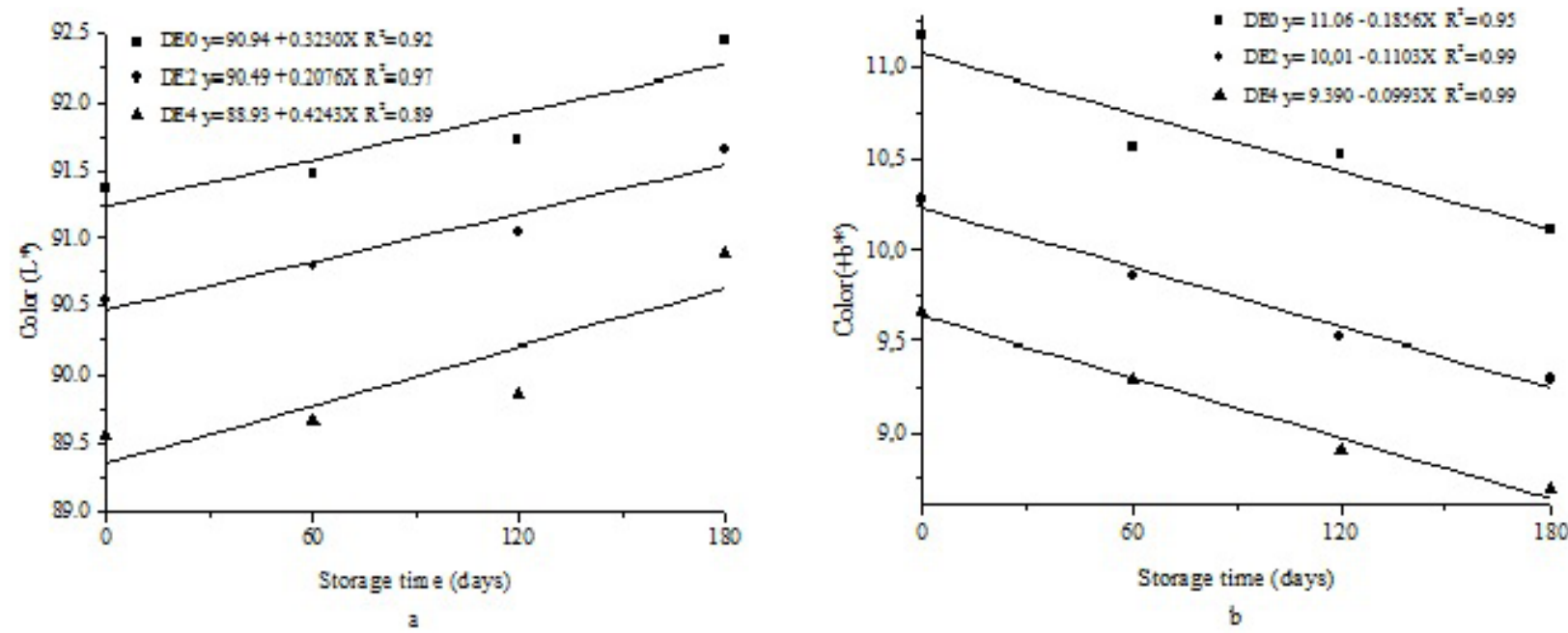

Figure 2 - Intensity of color component L* (lightness) (a) and intensity of color component $+b^{*}$ (yellow) (b) of flour from wheat grains treated with diatomaceous earth and stored for 180 days.

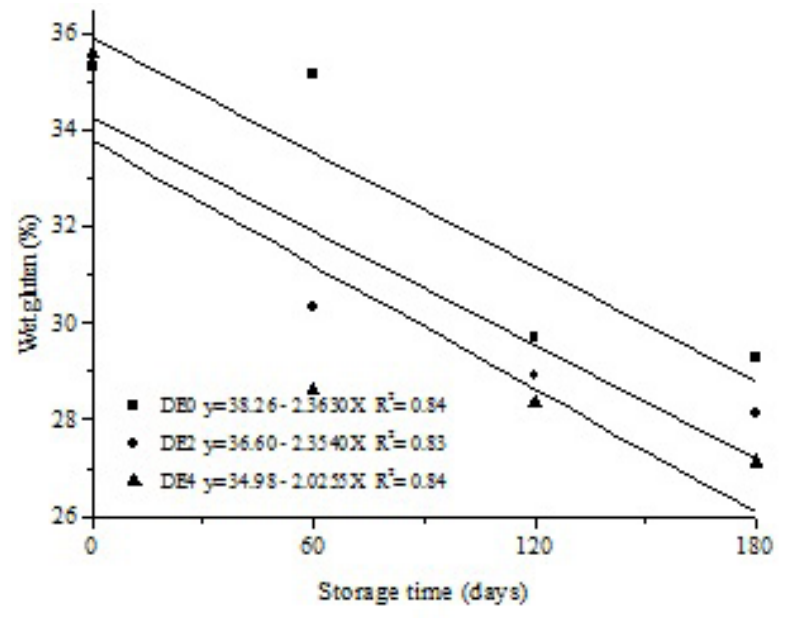

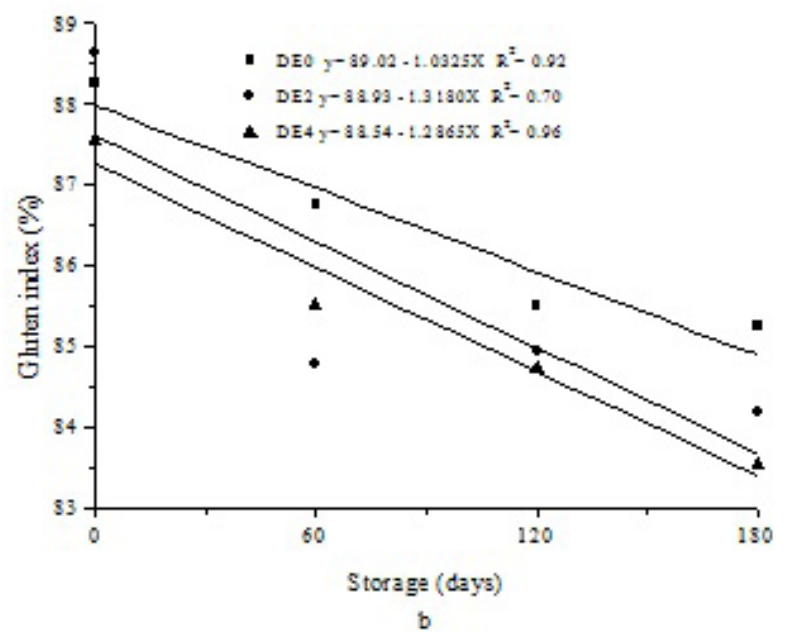

Figure 3 - Wet gluten content (\%) (a) and gluten index (\%) (b) in flour from wheat grains treated with diatomaceous earth and stored for 180 days. 
flour samples of wheat treated with DE2 and DE4. The gluten index is related to the qualitative composition of proteins, mainly to the allelic combination of glutenin subunits of high and low molecular weight, which are considered as the most important ones to the viscoelastic properties of the wheat flour dough (Torbica et al., 2007).

Alveography represents the work of dough deformation that indicates the flour bread-making quality. During the storage period, the value of gluten strength (W) increased significantly for DE0 (Figure 4a). The regression equation was significant; the quadratic terms were used in the adjustment, with coefficient of determination 0.95 . The inclination of the straight lines determined by the regression equations during the storage period was similar for $\mathrm{W}$ in DE2 and DE4, presenting non-significant regression models of 0.40 and 0.31 . Similar results relating wheat grain storage time to gluten strength improvement were reported by Carneiro et al. (2005) and Gutkoski et al. (2008).

Farinography evaluations, based on stability time (S), showed that, along the storage period, $\mathrm{S}$ increased in DE0 (Figure 4b), which may be attributed

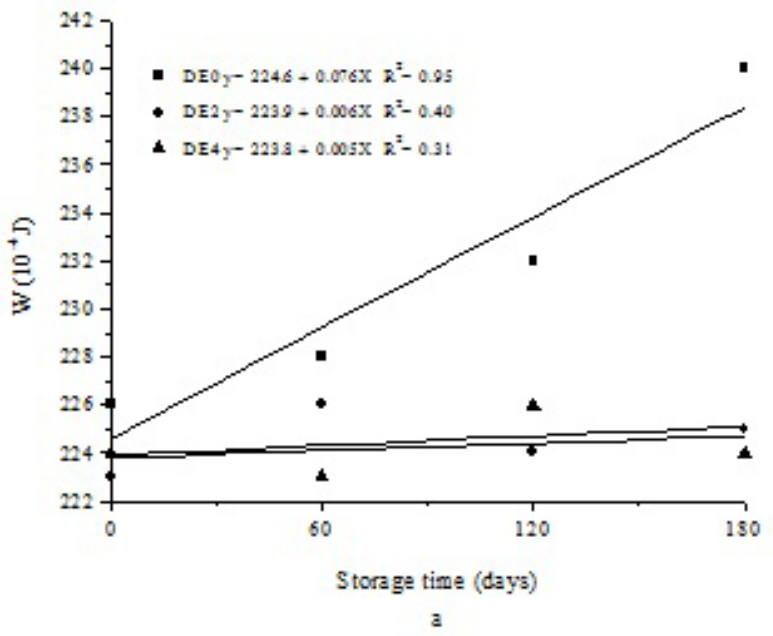

to the grain maturation during storage and which can be confirmed if analyzed together with gluten strength for this same sample. For treatments DE2 and DE4, stability diminished, and the lowest value of $\mathrm{S}$ was observed in the flour sample of wheat treated with 4.0 $\mathrm{g} \mathrm{kg}^{-1}$ of diatomaceous earth, which is justified by the presence of residue of diatomaceous earth leading to lower precipitation of proteins forming gluten. Among the treatments, only DE0 had similar behavior in relation to the rheological parameters, stability and gluten strength. Differently from the results of $\mathrm{S}$ obtained from this study, Korunic et al. (1996) reported that wheat flour treated with $300 \mathrm{mg} \mathrm{kg}^{-1}$ of diatomaceous earth presented greater stability and longer dough development time when compared to flour treated with $50 \mathrm{mg} \mathrm{kg}^{-1}$.

The cultivar used in this study has characteristics of wheat bread (Brasil, 2010). Due to the use of diatomaceous earth showed a decrease of technological quality, which was best seen in the sample DE4. However, it is questionable whether this behavior would remain that were tested a wheat cultivar breeder to, which has a higher protein content and may have exacerbated the effect.

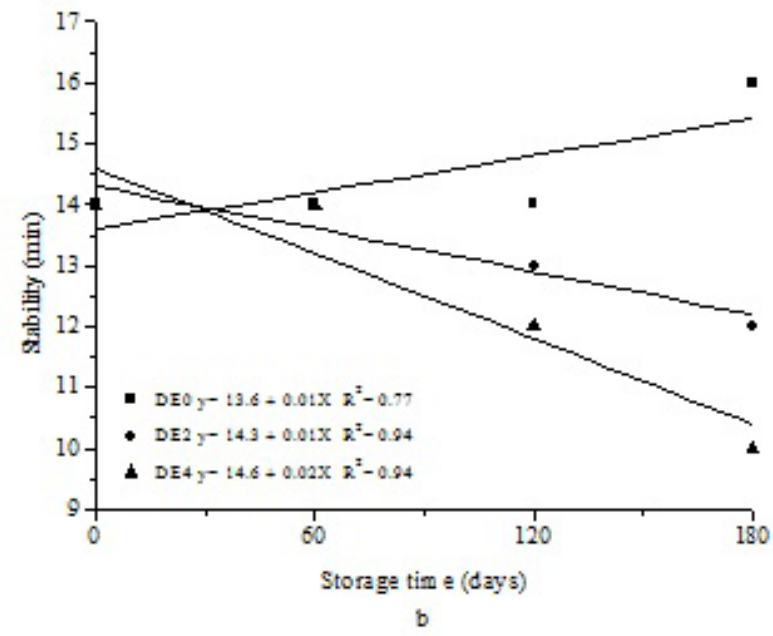

Figure 4 - Gluten strength (W) (a) and stability (S) (b) of flour from wheat grains treated with diatomaceous earth and stored for 180 days. 


\section{CONCLUSIONS}

The grain ash content and intensity of color component L* (lightness) of wheat flour increase proportionally to the application of increasing doses of diatomaceous earth and longer storage periods. The grain hectoliter mass, and values of $+b^{*}$ chromaticity coordinate (yellow), wet gluten content and gluten content in wheat flour diminish with the application of increasing doses of diatomaceous earth and longer storage periods. The gluten strength and dough stability of flour obtained from wheat grains without addition of diatomaceous earth increase with the storage period; this behavior was not observed in treatments with the application of 2.0 and $4.0 \mathrm{~g} \mathrm{~kg}^{-1}$ diatomaceous earth. The application of increasing doses of diatomaceous earth changes the physical and chemical characteristics of wheat grains stored, with consequent reduction of the flour technological quality.

\section{ACKNOWLEDGEMENTS}

We thank the National Board for Scientific and Technological Development for scholarships granted and financial support.

\section{REFERENCES}

AMERICAN ASSOCIATION OF CEREAL CHEMISTS. Official methods of analysis of the American Association of Cereal Chemists. $10^{\text {th }}$ ed. Saint Paul: AACC International, 2000.

ABID, H.; ALI, A.; HUSSAIN, A. Suitability of different wheat varieties grown in NWFP for bread making and effects of falling number on storage. Pakistan Journal of Nutrition. 8:616-619, 2009.

ATUI, M. B.; LAZZARI, F. A. LAZZARI, S. M. N. Avaliação de metodologia para detecção de resíduos de terra diatomácea em grãos de trigo e farinha. Instituto Adolfo Lutz. 62:11-16, 2003.

BHATTACHARYA, K.; RAHA, S. Deteriorative changes of maize, groundnut and soybean seeds by fungi in storage. Mycopathologia. 155(3):135-141, 2002.

\section{BRASIL. Ministério da Agricultura, do}

Abastecimento e da Reforma Agrária. Secretaria Nacional de Defesa Agropecuária. Regras para análise de sementes. Brasília, 2009. 399p.
BRASIL. Ministério da Agricultura, Pecuária e Abastecimento. Instrução Normativa $n^{\circ} 38$, de 30 de novembro de 2010. Regulamento técnico do trigo. Diário Oficial da República Federativa do Brasil, Brasília, DF, 1 dez. 2010. Seção 1, n.29, p.2.

CARNEIRO, L.M.T.A. et al. Diferentes épocas de colheita, secagem e armazenamento na qualidade de grãos de trigo comum e duro. Bragantia. 64:127-137, 2005.

FERREIRA, D.F. Sisvar 5.3, Build 75. 2010.

Disponível em: <http://www.dex.ufla.br/ danielff/ sisvar $>$. Acesso em: 13 abril, 2010.

FLEURAT-LESSARD, F. Qualitative reasoning and integrated management of the quality of stored grain: a promising new approach. Journal of Stored Products Research. 38:191-218, 2002.

GUTKOSKI, L. C.; JACOBSEN NETO, R. Procedimento para teste laboratorial de panificação pão de forma. Ciência Rural. 32:873-879, 2002.

GUTKOSKI, L. C. et al. Efeito do período de maturação de grãos nas propriedades físicas e reológicas de trigo.

Ciência e Tecnologia de Alimentos. 28:888-894, 2008.

KORUNIC, Z. et al. The effect of diatomaceous earth on grain quality. Postharvest Biology and Technology. 9:373-387, 1996.

KORUNIC, Z.; CENKOWSKI, S.; FIELDS, P. Grain bulk density as affected by diatomaceous earth and application method. Postharvest Biology and Technology. 13:81-89, 1998.

LORINI, I. Manual técnico para o manejo integrado de pragas de grãos de cereais armazenados. Passo Fundo: Embrapa, p.16-20, 2003.

. Manejo integrado de pragas de grãos armazenados. In: LORINI, I.; MIIKE, L.H.; SCUSSEL, V.M. (Ed) Armazenagem de grãos. Campinas: IBG, 2002. p.607- 621 .

ORTOLAN, F.; HECKTHEUER, L.H.; MIRANDA, M.Z. Efeito do armazenamento à baixa temperatura $\left(-4{ }^{\circ} \mathrm{C}\right)$ na cor e no teor de acidez da farinha de trigo. Ciência e Tecnologia de Alimentos. 30:55-59, 2010. 
PETERSON, C.J. et al. Grain color stability and classification of hard white wheat in the US. Euphytica. 119:101-106, 2001.

SANTOS, H.G. dos. et al. Sistema brasileiro de classificação de solos. Rio de Janeiro: Embrapa Solos, 2006. 306p.

TEDESCO, M.J.; VOLKWEISS, S.J.; BOHEN, H. Análises de solo, plantas e outros materiais, UFRGS:

Faculdade de Agronomia, Boletim Técnico. 5, 83-116, 1985.
TORBICA, A. et al. The influence of changes in gluten complex structure on technological quality of wheat (Triticum aestivum L.). Food Research International. 40(8):1038-1045, 2007.

VARDEMAN, E.A. et al. Efficacy of surface applications with diatomaceous earth to control Rhyzopertha dominica (F.) (Coleoptera: Bostrichidae) in stored wheat. Journal of Stored Products Research. 43:335-341, 2007. 